\title{
Strategi Implementasi Pengembangan Perkebunan Kelapa Sawit Di Era Industri 4.0
}

\author{
Nik Haryanti ${ }^{1}$, Adi Marsono ${ }^{2}$, \\ ${ }^{1}$ Institut Agama Islam Pangeran Diponegoro Nganjuk. Jl.Wilis Kramat,Nganjuk. \\ ${ }^{2}$ Institut Agama Islam Pangeran Diponegoro Nganjuk. Jl.Wilis Kramat,Nganjuk. \\ E-mail: nikharyanti1983@gmail.com
}

\begin{abstract}
Abstraks:
Revolusi industry 4.0 sebagai bentuk upaya transformasi menuju perbaikan proses dengan mengintegrasikan lini produksi dengan dunia siber, dimana proses produksi berjalan secara online melalui koneksi internet sebagai penopang utamanya. Kelapa sawit saat ini menjadi salah satu komoditas tanaman perkebunan andalan Indonesia dalam menghasilkan devisa. Industri kelapa sawit, memiliki pangsa pasar dengan pertumbuhan mencapai 9,23\% pada tahun 2017. Selain itu, industri tersebut juga menjadi penyumbang devisa terbesar dari sektor non-migas yang mencapai hingga 34,33\% di tahun 2017.Luas perkebunan kelapa sawit menurut Dirjen Perkebunan Departemen Pertanian telah berkembang menjadi 8,9 juta hektar di Indonesia. Strategi pengembangan kelapa sawit sangat perlu untuk dikembangkan, mengingat semakin kompetitifnya persaingan di pasar global dan juga sesuai dengan program peningkatan nilai tambah maka penting untuk mengetahui daya saing kelapa sawit di Indonesia dan menetapkan rumusan strategi yang mampu meningkatkan daya saing tersebut. Penelitian ini menggunakan jenis penelitian kepustakaan. Hasil penelitian ini menunjukkan bahwaIndustri 4.0 melalui inovasi dan teknologi berperan dalam meningkatkan produktivitas. Penerapan teknologi akan memperkuat keberlanjutan dari industri, termasuk industri sawit.Teknologi digital telah memudahkan banyak pekerjaan di industri sawit.Penyedia layanan cloud terkemuka di Indonesia, Datacomm Cloud Business bersama dengan mitra, memperkenalkan solusi Digital Perkebunan Terintegrasi SMART AGRICULTURE untuk Perkebunan pada umumnya dan perkebunan Kelapa Sawit.Smart Agriculture dapat menyongsong Industry 4.0 dan Tujuan Pembangunan Berkelanjutan.
\end{abstract}

Kata Kunci: Revolusi Industri 4.0,Pengembangan Perkebunan, Kelapa Sawit

\section{PENDAHULUAN}

Perkembangan yang telah mencapai era Revolusi Industri 4.0 diwarnai dengan implementasi buatam (artificial intelligence), super komputer, bigdata dan inovasi digital yang terjadi dalam peningkatan mengagumkan berdampak langsung pada ekonomi, industry, pemerintahan bahkan dalam bidang politik. Revolusi industry 4.0 yang ditandai dengan pelaksanaan industry yang cerdas mengacu pada peningkatan otomatisasi, komunikasi human to machine, artificial intelligence serta pengembangan teknologi digital yang berkelanjutan. Revolusi industry 4.0 sebagai bentuk upaya transformasi menuju perbaikan proses dengan mengintegrasikan lini produksi dengan dunia siber, dimana proses produksi berjalan secara online melalui koneksi internet sebagai penopang utamanya.

Indonesia telah menyusun peta jalan (road-map) industri 4.0 dengan menetapkan lima sektor manufaktur yang akan menjadi prioritas utama dalam pengembangannya, antara lain industri 
makanan dan minuman, otomotif, elektronika, tekstil, dan kimia.Kelima sektor industri tersebut diunggulkan mengingat selama ini telah menunjukkan kontribusinya yang besar terhadap pertumbuhan ekonomi nasional. Industri makanan dan minuman, khususnya industri kelapa sawit, memiliki pangsa pasar dengan pertumbuhan mencapai 9,23\% pada tahun 2017. Selain itu, industri tersebut juga menjadi penyumbang devisa terbesar dari sektor non-migas yang mencapai hingga $34,33 \%$ di tahun 2017.

Besarnya kontribusi sektor industri makanan dan minuman juga dapat dilihat dari nilai ekspor yang mencapai 31,7 miliar dollar AS pada tahun 2017, bahkan mengalami surplus neraca perdagangan bila dibandingkan dengan nilai impornya yang hanya sebesar 9,6 miliar dollar AS. Angka ini sekaligus menempatkan industri minyak sawit sebagai penyumbang devisa terbesar bagi negara.Guna meningkatan produktivitas dan efisiensi secara optimal maka teknologi pendukung revolusi industri 4.0 mutlak segera diimplementasikan, antara lain penerapan Internet of Things (IoT), Advance Robotic (AR), Artificial Intelligence (AI) dan Digitalized Infrastructure (DI).

Transformasi struktural dari sektor pertanian ke sektor industri juga telah meningkatkan pendapatan per kapita dan mengantarkan masyarakat Indonesia dari agraris menuju ekonomi yang mengandalkan proses peningkatan nilai tambah berbasis industri yang diakselerasi oleh perkembangan teknologi digital. Menghadapi revolusi industri 4.0 inilah sektor industri Kelapa Sawit perlu segera berbenah terutama dalam aspek teknologi digital. Hal ini mengingat penguasaan teknologi digital akan menjadi kunci utama yang menentukan daya saing Indonesia.Sebab jika tidak, maka industri kelapa sawit Indonesia akan semakin tertinggal dari negara-negara lainya. Jika tidak melakukan peningkatan kemampuan dan daya saing di sektor (industri) prioritas, kita bukan saja tidak akan mampu mencapai target, namun justru akan digilas oleh negara-negara lain yang lebih siap di pasar global maupun domestik.

Industri kelapa sawit global, Indonesia perlu secepatnya berbenah. Efisiensi proses dan operasional mutlak segera dilakukan khususnya menyangkut kegiatan-kegiatan yang melibatkan banyak tenaga kerja seperti misalnya pekerjaan lapangan (infield activity) antara lain perawatan tanaman, perawatan lahan, kegiatan pemupukan, penyiangan, pemanenan dan pengangkutan buah hingga penimbangan dan sortasi. Hal ini mengingat di sektor ini ditengarai kerapkali terjadi inefisiensi waktu dan biaya.

Teknologi digital telah memudahkan banyak pekerjaan di industri sawit. Kini tak perlu lagi membuat data statistik yang dikumpulkan dari sejumlah kebun sawit secara manual. Kemudahan dan keunggulan lain dari teknologi digital adalah dapat mengcapture gambar atau foto dari tandan buah segar, selain juga lokasi kebunnya secara presisi dengan menggunakan tablet yang dapat mengakses GPS. Dengan begitu, para manager lapangan tak hanya dapat dengan mudah melacak dan memantau aktivitas di kebun secara real-time, tapi mereka juga dapat melihat sendiri kualitas buah sawit dan 
mengetahui dengan tepat area mana saja yang mengalami masalah. Dan hebatnya, semua itu tak perlu kehadiran mereka di lapangan.

Selain kemudahan dalam mentransfer data dari lapangan ke lembar Excel di komputer dan juga membuat laporan mengenai kualitas buah sawit, digitalisasi juga memudahkan dalam mendata kehadiran karyawan dan pekerja lapangan untuk kemudian mengolah data tersebut untuk keperluan pengupahan dan insentif.Pada prinsipnya penggunaan teknologi digital adalah mengganti proses manual dengan teknologi digital, sehingga dapat menekan biaya operasional, mempercepat pengiriman data dan informasi, menciptakan transparansi, dan menghindari manipulasi laporan. Sistem digital dapat menekan kecurangan karena terdapat kegiatan kontrol secara digital, sehingga akan tercipta efisiensi biaya dan membantu peningkatan produktivitas industri perkebunan kelapa sawit di Indonesia.

\section{METODE PENELITIAN}

Penelitian ini menggunakan jenis penelitian kepustakaan. Penelitian kepustakaan sebagai suatu penelitian yang dilaksanakan dengan mereview dari berbaga jurnal dan buku-buku referensi terkait, yang pada akhirnya dapat dianalisis dan disimpulkan dari berbagai sumber yang didapatkan oleh peneliti tersebut. Pendekatan penelitiannya adalah penelitian kualitatif yang dilakukan dengan berorientasi pada gejala alamiah yang terjadi dan penelitian ini tidak dilakukan di laboratorium. Penelitian yang dilakukan bersifat deskriptif dimana peneliti mengumpulkan kata-kata bukan berupa serangkaian angka untuk penelitian ini yang pada intinya kata-kata tersebut bisa memberikan gambaran atau menyajikan permasalahan dan pemecahan masalah yang ada. Analisis data yang digunakan adalah dengan menganalisis isi, dimana dalam analisis lebih mengedepankan pada menguraikan isi dari berbagai proposisi yang telah ada yang terlahir dari berbagai teori dan analisis sebelumnya yang dilakukan oleh peneliti lain.

\section{HASIL DAN PEMBAHASAN}

\section{Strategi Pengembangan}

Srategi pengembangan adalah suatu proses yang meningkatkan efektifitas keorganisasian dengan mengintergrasikan keinginan individu akan pertumbuhan dan perkembangan tujuan keorganisasian. secara khusus proses ini merupakan usaha mengadakan perubahan secara berencana yang meliputi suatu system total sepanjang periode tertentu, dan usaha mengadakan perubahan ini berkaitan dengan misi organisasi (Gibson, 1990).

Srategi pengembangan adalah usaha yang terencana dan berkelanjutan untuk menerapkan ilmu perilaku guna pengembangan system dengan menggunakan metode-metode refleksi dan 
analisis diri (Umar Nimran, 1997). Strategi pengembangan adalah cara atau srategi yang digunakan oleh wadah atau tempat guna proses suatu perubahan berencana yang memerlukan dukungan semua pihak, antara lain pengelola dan karyawan dengan perubahan-perubahan itu diharapkan dapat mengembangkan dan meningkatkan suatu perusahaan, yang memerlukan usaha jangka pendek, menengah, dan panjang guna menghadapi perubahan yang akan terjadi pada masa mendatang.

Pengembangan suatu perusahaan dibutuhkan strategi yang efektif. Strategi yang efektif adalah strategi yang mendorong terciptanya suatu keselarasan yang sempurna antara organisasi dengan lingkungannya dan antara organisasi dengan pencapaiannya dari tujuan strategisnya (Griffin, 2004).Dengan mengimplementasikan strategi yang efektif maka alternatif strategi dapat dicapai sebuah lembaga tersebut dalam mencapai tujuannya.

Strategi dapat dikelompokkan atas empat kelompok strategi, yaitu:

\section{a. Strategi Integrasi Vertikal (Vertical Integration Strategy)}

Strategi ini menghendaki agar perusahaan melakukan pengawasan yang lebih terhadap distributor, pemasok, dan/atau para pesaingnya, misalnya melalui merger, akuisisi atau membuat perusahaan sendiri.

\section{b. Strategi Intensif (Intensive Strategy)}

Strategi ini memerlukan usaha-usaha yang intensif untuk meningkatkan posisi persaingan perusahaan melalui produk yang ada.

\section{c. Strategi Diversifikasi (Diversification Strategy)}

Strategi ini dimaksudkan untuk menambah produk-produk baru. Strategi ini makin kurang populer, paling tidak ditinjau dari sisi tingginya tingkat kesulitan manajemen dalam mengendalikan aktivitas perusahaan yang berbeda-beda.

\section{d. Strategi Bertahan (Defensive Strategy)}

Strategi ini bermaksud agar perusahaan melakukan tindakan-tindakan penyelamatan agar terlepas dari kerugian yang lebih besar, yang pada ujung-ujungnya adalah kebangkrutan (Umar, 2001)

\section{Kelapa Sawit}

Kelapa sawit adalah tumbuhan industri penghasil minyak masak, minyak industri, maupun bahan bakar (biodiesel). Tinggi kelapa sawit dapat mencapai 2,4 meter. Bunga dan buahnya berupa tandan, serta bercabang banyak. Buahnya kecil dan apabila masak, berwarna merah kehitaman. Daging buahnya padat. Daging dan kulit buahnya mengandung minyak. Minyaknya digunakan sebagai bahan minyak goreng, sabun dan lilin. Buah sawit terdiri dari dua bagian utama yaitu perikarpium yang terdiri dari epikaprium dan mesokaprium, dan biji yang terdiri dari endokaprium, endosperm, dan lembaga atau embrio. Epikaprium adalah kulit buah yang keras dan licin, sedangkan mesokaprium yaitu daging buah yang berserabut dan mengandung minyak dengan rendemen paling 
tinggi. Endokaprium merupakan tempurung berwarna hitam dan keras. Endosperm atau disebut juga kernel merupakan penghasil inti sawit, sedangkan lembaga atau embrio merupakan bakal tanaman (Siradjuddin, 2015).

Sawit umumnya tumbuh dan ditanam disekitar $15^{\circ} \mathrm{LU}-15^{\circ} \mathrm{LS}$ pada lahan yang datar, bergelombang sampai berbukit (kemiringan 0-30\%). Curah hujan yang optimum untuk tanaman sawit adalah 2.000-2.500 mm/tahun, tidak memiliki defisit air, serta penyebarannya merata sepanjang tahun. Sawit merupakan tanaman tropis sehingga menghendaki temperatur yang hangat sepanjang tahun dengan kisaran optimal $24-28^{\circ} \mathrm{C}$, temperatur minimum (Tmin) $18^{\circ} \mathrm{C}$, temperatur maksimum (Tmax) $32^{\circ} \mathrm{C}$, kelembaban udara $80 \%$, dan penyinaran matahari 5-7 jam/hari (Triyono, et.al, 2015).

\section{Perkembangan Kelapa Sawit di Era Industri 4.0}

Inovasi dan teknologi adalah hal yang sering dibicarakan di masa Industri 4.0. Industri 4.0 melalui inovasi dan teknologi berperan dalam meningkatkan produktivitas. Penerapan teknologi akan memperkuat keberlanjutan dari industri, termasuk industri sawit.Berdasarkan data Kementerian Perindustrian terdapat 191 perusahaan eksportir minyak kelapa sawit, didominasi oleh ekspor Crude Palm Oil (CPO). Sedangkan berdasarkan data trademap.org ada 144 perusahaan pengekspor minyak kelapa sawit di Indonesia. Produsen terbesar kelapa sawit yaitu Grup Sinar Mas Golden Agri Resources Ltd (GAR), Wilmar Internasional Limited, dan Cargill Internasional Corp. Produsen kelapa sawit di Indonesia didominasi oleh beberapa grup perusahaan swasta. Seperti GAR memiliki anak perusahaan PT Sinar Mas Agro Resources and Technology Tbk (SMART) pada tahun 2016 memproduksi 627.034 ton CPO dan 155.288 ton Palm Kernel Oil (PKO).

Perusahaan kelapa sawit terbesar lainnya di Indonesia yaitu PT Astra Agro Lestari Tbk. Perusahaan ini mampu memproduksi 1,55 juta ton CPO dan berbagai turunan kelapa sawit seperti Refined, Bleached and Deodorized Palm Oil (RBDPO) sebesar 118.012 ton, dan Olein 301.034 ton. Ada pula PT Asian Agri yang mampu memproduksi CPO sebesar 1 juta ton. Mayoritas perusahaan kelapa sawit tidak hanya fokus pada satu mata rantai produksi kelapa sawit. Akan tetapi melakukan integrasi bisnis mulai dari memiliki perkebunan kelapa sawit, pabrik CPO dan pabrik pengolahan. 


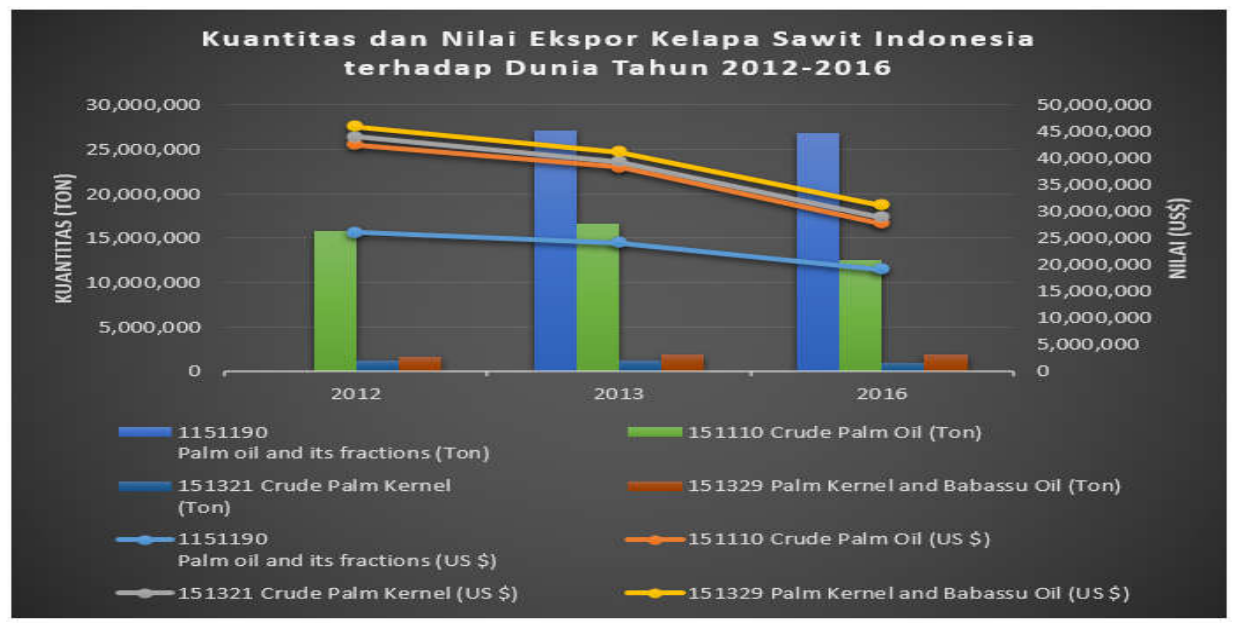

Gambar 1 : Kuantitas dan Nilai Ekspor Kelapa Sawit Indonesia terhadap Dunia Tahun 2012-2016 Sumber : diolah dari trademap.org

Ekspor produk kelapa sawit Indonesia terus mengalami kenaikan dalam hal kuantitas. Akan tetapi, terdapat masalah penurunan nilai ekspor produk kelapa sawit Indonesia. Sehingga kenaikan produksi tidak diikuti dengan kenaikan nilai beli. Berdasarkan gambar 1 terlihat bahwa terjadi penurunan bagi produk kelapa sawit HS 6 digit. Selain itu, ada pula penurunan ekspor CPO dan juga Crude Palm Kernel (CPK) .

Seperti pada tahun 2012 ekspor CPO sebesar 15.736 .570 ton menurun pada tahun 2016 menjadi 12.564198. Nilai ekspor pun menurun hingga dua kali lipat, dari US\$16.465.631 pada tahun 2012 menjadi US\$8.654.358 pada tahun 2016. Jadi berdasarkan gambar 1 diketahui bahwa produk kelapa sawit yang rentan mengalami penurunan terus menerus yaitu CPO dan CPK.

Di sisi lain, negara importir minyak kelapa sawit Indonesia sangat berpusat di beberapa negara. Negara terbesar yang mengimpor minyak kelapa sawit dari Indonesia yaitu India, Tiongkok dan Belanda. Akan tetapi terdapat beberapa tantangan ekspor ke negara-negara tersebut. Seperti India yang mengurangi impor minyak kelapa sawit dari Indonesia pada tahun 2012 ke 2016. Pada tahun 2012 India mengimpor 3.614.821 ton pada tahun 2012 menurun menjadi 2.948.984 pada tahun 2016. Bahkan untuk CPK, India mengurangi impor hingga 50\%. Pada tahun 2012 India mengimpor 62.729 ton CPK dan menurun pada tahun 2016 menjadi 32.962 ton. Penurunan impor India ini terjadi pada produk sawit yang lain kecuali palm oil and its fractions yang mengalami peningkatan. Peningkatan terjadi pada tahun 2012 sebesar 1.638.986 ton menjadi 2.456.492 ton pada tahun 2016 .

Permintaan palm oil and its fractions di negara lain juga meningkat. Nilai ekspor di Belanda dan Pakistan bahkan meningkat hingga dua kali lipat. Di Belanda pada tahun 2012 nilai ekspornya sebesar US\$218.264 meningkat pada tahun 2016 menjadi 424.563. Padahal tidak ada peningkatan jumlah ekspor yang signifikan. Hal ini bisa jadi potensi bahwa palm oil and its fractions dapat memberikan keuntungan yang besar bagi pelaku industri sawit. 
Negara lain yang berpotensi untuk menjadi mitra ekspor minyak kelapa sawit Indonesia yaitu Pakistan. Pakistan terus melakukan ekspor minyak kelapa sawit dari Indonesia dan meningkat sangat tinggi pada tahun 2012 ke 2016. Peningkatannya mencapai 120\% untuk palm oil and its fractions. Jadi hal ini menjadi tambahan bukti bahwa Indonesia perlu meningkatkan diversifikasi produk kelapa sawit.

Selama ini ekspor minyak kelapa sawit Indonesia terfokus pada beberapa negara industri seperti Tiongkok dan India. Negara-negara tersebut mengolah minyak kelapa sawit menjadi berbagai produk turunan. Menurut Enny Sri Hartati selaku Direktur Eksekutif Institute For Development of Economics and Finance (INDEF), apabila Indonesia menggeser ekspor menjadi sektor produk, maka pangsa pasar dapat meluas ke negara-negara nonindustri seperti Afrika Selatan, Timur Tengah, dan negara-negara Amerika Latin.

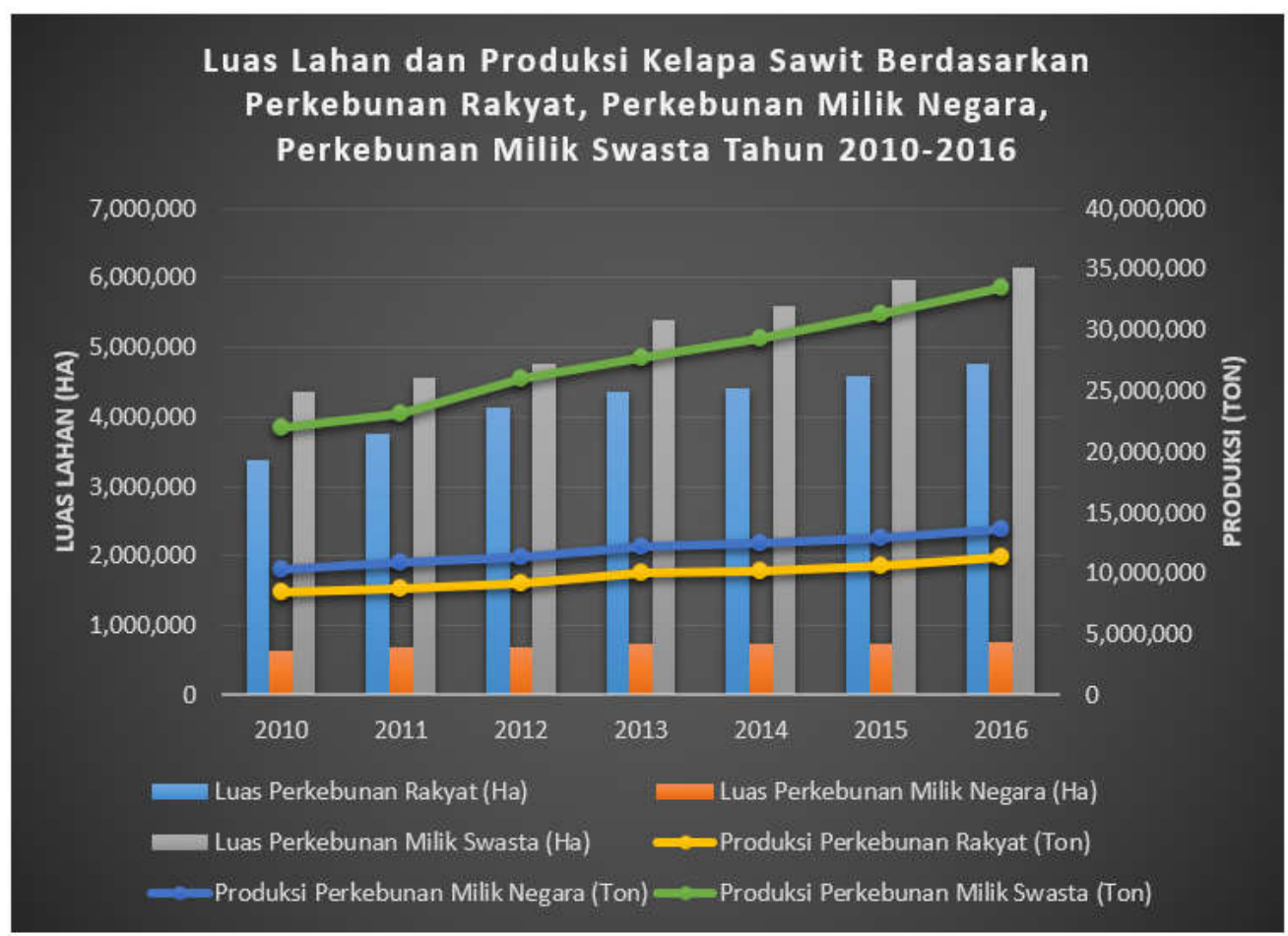

Gambar 2 : Luas Lahan dan Produksi Kelapa Sawit Berdasarkan Perkebunan Rakyat, Perkebunan Milik Negara, Perkebunan Milik Swasta Tahun 2010-2016

Sumber : Direktorat Jenderal Perkebunan, 2015

Gambar 2 menunjukkan adanya peningkatan lahan perkebunan rakyat dan swasta, akan tetapi perkebunan rakyat tidak mengalami kenaikan signifikan. Tetapi, produktivitas perkebunan rakyat cukup tertinggal dibandingkan perkebunan swasta. Setiap tahun perkebunan rakyat meningkat sebanyak 100 ha hingga 400 ha. Akan tetapi peningkatannya tidak sebanding dengan peningkatan produksi. Hal ini bisa juga karena usia kelapa sawit, akan tetapi apabila dibandingkan dengan perkebunan swasta maka terlihat ketimpangan produktivitas perkebunan rakyat. 
Seperti sejak tahun 2010 terjadi peningkatan hingga 400 ha dan begitu pula perkebunan swasta, akan tetapi peningkatan produksi perkebunan rakyat sekitar 100.000 ton hingga 600.000. Sedangkan perkebunan swasta mengalami peningkatan hingga 600.000 ton hingga 2.500.000 ton. Maka peningkatan produktivitas perkebunan perlu ditingkatkan karena hal ini berdampak pada sedikitnya minyak yang dihasilkan, padahal lahan yang dimiliki oleh perkebunan rakyat cukup besar. Bahkan tidak jauh berbeda dengan luas perkebunan swasta. Pada gambar 1 pun terlihat pada tahun 2015 perkebunan rakyat dengan luas lahan 4.763.797 ha menghasilkan 11.267.161 ton. Sedangkan perkebunan swasta dengan 6.153.277 ha mampu menghasilkan 19.927.699.

Masalah produktivitas di atas terjadi karena beberapa faktor, seperti masalah usia pohon kelapa sawit dan teknologi. Akibatnya ada masalah rendahnya produktivitas. Perkebunan rakyat hanya mampu memproduksi 2-3 ton per ha, sedangkan perkebunan swasta mampu mencapai 4 ton per ha. Selain itu, produksi tersebut jauh lebih rendah dibandingkan Malaysia yang mampu menghasilkan 10 ton per ha.

Ekspor minyak kelapa sawit Indonesia terus meningkat karena faktorintensive margin. Produk yang telah lama diproduksi ekspornya terus meningkat, seperti CPO dan PKO. Sedangkan extensive margin tidak memengaruhi peningkatan ekspor secara signifikan. Rendahnya extensive margin perlu mendapat perhatian dari pemerintah. Apabila tidak ada diversifikasi produk dan pasar maka akan ada potensi kekalahan Indonesia dalam bersaing dengan produsen kelapa sawit lainnya. Hal ini karena produk yang dihasilkan hampir sama dan tidak ada inovasi. Badan Pengelola Dana Perkebunan Kelapa Sawit (BPDP) memiliki rencana untuk membuat program dana abadi kelapa sawit. Dana tersebut akan mendukung industri kelapa sawit agar lebih berkelanjutan. Dana abadi dikumpulkan dari pungutan ekspor CPO yang setiap tahunnya mencapai 5,7 triliun. Jadi adanya BPDP harusnya bisa dimanfaatkan dengan maksimal untuk menyelesaikan masalah di atas.

\section{Implementasi Pengembangan Perkebunan Kelapa Sawit di Era Industri 4.0}

Perkebunan di Indonesia dicakup dalam Pasal 4 Undang-Undang Nomor 18 Tahun 2004 (telah diubah menjadi Undang-Undang No. 39/2014) bahwa perkebunan mempunyai tiga fungsi, yaitu (1) fungsi ekonomi (peningkatan kemakmuran dan kesejahteraan rakyat serta penguatan struktur ekonomi wilayah dan nasional); (2) fungsi ekologi (peningkatan konservasi tanah dan air, penyerapan karbon, penyedia oksigen, dan penyangga kawasan lindung; serta (3) fungsi sosialbudaya (sebagai perekat dan pemersatu bangsa). Dengan demikian, perkebunan kelapa sawit (industri hilirnya) merupakan bentuk dan cara pemanfaatan serta pelestarian multifungsi yang melekat pada perkebunan kelapa sawit tersebut secara lintas generasi. Melalui pembudidayaan tanaman kelapa sawit (perkebunan kelapa sawit), fungsi ekonomi, fungsi sosial, dan fungsi ekologis tersebut tidak hanya dinikmati oleh generasi sekarang, tetapi juga oleh generasi yang akan datang. 
Bahkan, pelestarian biodiversity melalui pembudidayaan merupakan cara yang efektif dan berdaya guna.

Kelestarian multifungsi perkebunan kelapa sawit Indonesia juga dinikmati masyarakat dunia, baik yang terlibat langsung maupun tidak langsung. Hampir semua negara di seluruh dunia menikmati manfaat ekonomi/konsumsi produk oleopangan dan oleokimia melalui perdagangan internasional. Sebagai satu ekosistem global, masyarakat internasional juga menikmati jasa kelestarian siklus karbon dioksida, oksigen, dan air yang dihasilkan dari perkebunan kelapa sawit. Secara empiris fungsi ekonomi dari industri minyak sawit telah banyak dibuktikan berbagai ahli, antara lain sumber devisa dan pendapatan negara, pembangunan ekonomi daerah, serta peningkatan pendapatan petani (Sipayung \& Purba, 2015; Rofiq, 2013).

Manfaat ekonomi dari industri minyak sawit juga dinikmati masyarakat Uni Eropa. Penelitian yang dilakukan Europe Economics berjudul "Economic Impact of Palm Oil Import in the EU" pada 2014 mengungkap bahwa penggunaan minyak sawit di Uni Eropa (EU) menciptakan "kue" ekonomi yang lumayan besar bagi EU setiap tahun, yakni menciptakan kesempatan kerja bagi 117 ribu orang. Penggunaan minyak sawit pada 16 negara anggota EU menciptakan pendapatan 5,8 miliar euro setiap tahun dalam produk domestik bruto, penerimaan pajak 2,6 miliar euro. Lima negara EU terbesar menikmati "kue" ekonomi tersebut adalah Italia, Spanyol, Jerman, Prancis, Belanda, dan Finlandia. Kelima negara terbesar ini memiliki industri hilir yang menggunakan minyak sawit, seperti industry oleokimia, industri oleopangan, dan industry biodiesel. Setiap tahun, EU mengimpor 6,4 juta ton minyak sawit dari Indonesia dan Malaysia. Sekitar 40\% yang diimpor tersebut digunakan untuk energi, baik biodiesel maupun pembangkit listrik, sedangkan sisanya, yakni $60 \%$, digunakan untuk bahan pangan, bahan kosmetik, dan toiletries (Europe Economics, 2014).

Penyedia layanan cloud terkemuka di Indonesia, Datacomm Cloud Business bersama dengan mitra, memperkenalkan solusi Digital Perkebunan Terintegrasi SMART AGRICULTURE untuk Perkebunan pada umumnya dan perkebunan Kelapa Sawit dan Perkebunan Tebu pada khususnya.Pertumbuhan bisnis Perkebunan Kelapa Sawit di Indonesia berkembang sangat cepat, karena minyak sawit adalah industri terpenting di Indonesia yang menyumbang antara 1,5 - 2,5 persen dari produk domestik bruto (PDB) negara.Menurut Gabungan Industri Minyak Nabati Indonesia (GIMNI) diperkirakan tahun depan akan terjadi kekurangan minyak kelapa sawit sampai 2 juta ton. Hal ini menjadi sebuah tantangan bagi produsen kelapa sawit kedepannya. SMART AGRICULTURE dapat menyongsong Industry 4.0 dan Tujuan Pembangunan Berkelanjutan. Selain itu, beberapa tantangan yang dihadapi produsen kelapa sawit saat ini adalah kurangnya produktivitas perkebunan akibat tingginya biaya pemeliharaan kebun, keamanan, pembibitan dan pupuk, serta tenaga kerja yang kurang efisien. 
Menyikapi semakin berkembangnya perkebunan kelapa sawit di era industriu 4.0, maka harus diadakan aliansi partner untuk memberikan integrasi solusinya yaitu :

1. Komunikasi antara machine to machine yang menjadi kendala di perkebunan yang tidak ter-cover oleh jaringan GSM, kami sediakan solusi RPMA (random phase multiple access). Komunikasi ini untuk dapat memberikan data real time dari sensor yang ada di lapangan ke dalam sistem seperti sensor ketinggian muka air, sensor curah hujan dan arah angin dan sensor lainnya.

2. Modul Pemantauan Aset Bergerak dan Stasioner bernama SIOPAS atau SIOPASPLUS, aset dapat dipantau dan dimanfaatkan secara maksimal (optimalisasi aset).

3. Modul Pemantauan dan Pelacakan pekerja bernama GEOHRyangmeningkatkan efektivitas dan efisiensi karyawan yang bekerja di lapangan. Mengintegrasikan sistem absensi di kantor dengan sistem Portal Web yang terintegrasikan dengan absensi dan tracking karyawan menggunakan mobile phone disamping fungsi panic button untuk situasi genting karyawan di lapangan.

4. Modul Management data Geospatial berikut engine development yang akan memungkinkan pihak perkebunan mempercepat pembangunan sistem informasi geospatial berbasis web yang juga mengintegrasikan data transaksi dari ERP system ke dalam data Geospatial (peta) bernama OSMAP.

5. Modul Analisa tergabung dengan WebGIS dan MAP-GIS yangmenyediakan analisa data berdasarkan citra satelit dalam 1 - 2 minggu, dengan resolusi tinggi 3 - 5 meter yang dikombinasikan dengan sensor di lapangan dan platform Artificial Intelligence untuk menyediakan data. Hal itu terdiri dari: Forecasting Panen dari Kebun, Pengelolaan Hama, Peringatan Kebakaran, Kesehatan Tanaman, Pengelolaan Air, Risiko Kebakaran, dan lain-lain bernama AGRISOURCE.

6. Modul yang dapat meningkatkan utilisasi transportasi, Keselamatan bekerja dan tentunya efisiensi di logistik dan transport bernama OSLOG. Modul ini akan membantu operasional yang mencakup proses penjualan menerima pesanan, memantau pesanan, dan menyelesaikan pesanan. Data yang diberikan adalah performa penjualan, pengiriman tepat waktu, jarak waktu, key performance indicator (KPI) Pengemudi, dan lain-lain.

7. Modul ERP untuk Perkebunan bernama EPCS-IPLAS. Memberi pihak perkebunan akses mudah ke informasi operasional utama untuk pengambilan keputusan dan membuat keputusan lebih jelas, lebih cepat, dan lebih mudah dengan ERP khusus perkebunan Modul Kegiatan Operasional Lapangan bernama EPCS. EPCS (electronic plantation control system) dikembangkan dalam perangkat android, membantu administrasi manual pekerjaan umum, panen, transportasi, dan sortasi pabrik untuk proses input dan pelaporan secara cepat, mengurangi kesalahan serta ketidaksesuaian karena telah dilengkapi dengan global positioning system (GPS) data dapat 
berupa gambar real di lapangan. EPCS akan mengurangi data ganda dan penggunaan laporan fisik. (https://www.liputan6.com)

\section{KESIMPULAN}

Industri 4.0 melalui inovasi dan teknologi berperan dalam meningkatkan produktivitas. Penerapan teknologi akan memperkuat keberlanjutan dari industri, termasuk industri sawit.Industri kelapa sawit global, Indonesia perlu secepatnya berbenah. Efisiensi proses dan operasional mutlak segera dilakukan khususnya menyangkut kegiatan-kegiatan yang melibatkan banyak tenaga kerja seperti misalnya pekerjaan lapangan (infield activity) antara lain perawatan tanaman, perawatan lahan, kegiatan pemupukan, penyiangan, pemanenan dan pengangkutan buah hingga penimbangan dan sortasi. Hal ini mengingat di sektor ini ditengarai kerapkali terjadi inefisiensi waktu dan biaya.

Teknologi digital telah memudahkan banyak pekerjaan di industri sawit. Kini tak perlu lagi membuat data statistik yang dikumpulkan dari sejumlah kebun sawit secara manual. Kemudahan dan keunggulan lain dari teknologi digital adalah dapat mengcapture gambar atau foto dari tandan buah segar, selain juga lokasi kebunnya secara presisi dengan menggunakan tablet yang dapat mengakses GPS. Dengan begitu, para manager lapangan tak hanya dapat dengan mudah melacak dan memantau aktivitas di kebun secara real-time, tapi mereka juga dapat melihat sendiri kualitas buah sawit dan mengetahui dengan tepat area mana saja yang mengalami masalah. Dan hebatnya, semua itu tak perlu kehadiran mereka di lapangan.

Penyedia layanan cloud terkemuka di Indonesia, Datacomm Cloud Business bersama dengan mitra, memperkenalkan solusi Digital Perkebunan Terintegrasi SMART AGRICULTURE untuk Perkebunan pada umumnya dan perkebunan Kelapa Sawit dan Perkebunan Tebu pada khususnya.Pertumbuhan bisnis Perkebunan Kelapa Sawit di Indonesia berkembang sangat cepat, karena minyak sawit adalah industri terpenting di Indonesia yang menyumbang antara 1,5 - 2,5 persen dari produk domestik bruto (PDB) negara.Menurut Gabungan Industri Minyak Nabati Indonesia (GIMNI) diperkirakan tahun depan akan terjadi kekurangan minyak kelapa sawit sampai 2 juta ton. Hal ini menjadi sebuah tantangan bagi produsen kelapa sawit kedepannya. SMART AGRICULTURE dapat menyongsong Industry 4.0 dan Tujuan Pembangunan Berkelanjutan. Selain itu, beberapa tantangan yang dihadapi produsen kelapa sawit saat ini adalah kurangnya produktivitas perkebunan akibat tingginya biaya pemeliharaan kebun, keamanan, pembibitan dan pupuk, serta tenaga kerja yang kurang efisien. 


\section{UCAPAN TERIMA KASIH}

Untuk dapat menyelesaikan penelitian ini, penulis mendapatkan berbagai bantuan dari beberapa pihak. Oleh karena itu penulis berkewajiban menyampaikan rasa terima kasih sedalam-dalamnya, terutama kepada: Rektor Institut Agama Islam Pangeran Diponegoro (IAI PD) Nganjuk yang telah memberikan izin kepada penulis untuk dapat menyelesaikan studi akhir. Dekan Fakultas Syariah dan Ekonomi Islam, yang telah memberikan izin dan pengarahan pada peneliti.

\section{DAFTAR RUJUKAN}

Gibson, James L. Organisasi Dan Manajemen, Perilaku Struktur Dan Proses, Terj. Djoerban Wahid Jakarta: Erlangga, 1990.

Nimran, Umar. Perilaku Organisasi, Surabaya: Citra Media, 1997.

Griffin, Ricky W. Manajemen Jilid I, alih bahasa Gina Gania, Ed. Wisnu Chandra Kristiaji, Jakarta: Erlangga, 2004,

Umar, Husein. Strategic Management in Action, Jakarta: PT Gramedia Pustaka Utama, 2001

Siradjuddin, Irsyadi. Dampak Perkebunan Kelapa Sawit terhadap Perekonomian Wilayah di Kabupaten Rokan Hulu, Jurnal Agroteknologi, Vol. 5 No. 2, 2015

Triyono, Djoko et.al, Strategi Pengembangan Kebun Kelapa Sawit Lahan Gambut Kabupaten Kubu Raya, Jurnal Social Economic of Agriculture, Volume 4, Nomor 22015.

Sipayung. T., \& Purba, J. H. V. 2015. Ekonomi agribisnis minyak sawit. Bogor: Palm OilAgribusiness Strategic Policy Institute.

Rofiq, H. N. 2013. Economic analysis of oil palm plantation and oil palm productivity in effect on per capita income in Indonesia. International Instituteof Social Studies. The Netherlands: The Huge.

Europe Economics. (2014). The economic impact of palm oil imports in the EU. London: Europeeconomics, Chancery House, 53-64 ChanceryLane. 